\title{
THE EVALUATION OF THE EFFECT OF CHALCEDONY DUST ON THE REACTION OF ALKALIS WITH REACTIVE AGGREGATE IN CEMENT MORTARS
}

\section{OCENA WPŁYWU MĄCZKI CHALCEDONITOWE NA PRZEBIEG REAKCJI ALKALIÓW Z KRUSZYWEM REAKTYWNYM W ZAPRAWACH CEMENTOWYCH}

DOI: $10.30540 / \mathrm{sae}-2018-002$

\begin{abstract}
Chalcedony dust can be used as a mineral additive in cements and concretes. This material can act as a pozzolan and prevent the expansion caused by the alkali-silica reaction. The paper presents the examination of cement mortars with reactive opal aggregate and various quantities of chalcedony dust conducted using a long-term method as set out in the ASTM C227. A petrographic analysis as well as tests of potential reactivity of opal aggregate were carried out by chemical method as specified in the ASTM C289. The microstructure of cement mortars with chalcedony dust and opal was also examined. The tests showed a positive effect of the chalcedony dust additive on the reduction of the expansion caused by the alkali-silica reaction compared to the mortars without the additive. The addition of $20 \%$ of chalcedony dust to cement mortars lowers the expansion to a safe level that does not exceed $0.1 \%$ after 360 days (as set out in the ASTM C227).
\end{abstract}

Keywords: alkali-silica reaction, chalcedony dust, mineral additive, reactive aggregate, cement composites

\section{Streszczenie}

Mączka chalcedonitowa może być wykorzystywana jako dodatek mineralny do cementów oraz betonów. Surowiec ten może działać jak pucolana i zapobiegać ekspansji wywołanej reakcją alkalia-krzemionka. W referacie przedstawiono badania zapraw cementowych z reaktywnym kruszywem opalowym oraz różna ilościq dodatku mączki chalcedonitowej metoda dlugoterminowa wg ASTM C227. Wykonano analize petrograficzna oraz badania potencjalnej reaktywności kruszywa opalowego metoda chemiczna zawarta w normie ASTM C289. Przeprowadzono również badania mikrostruktury zapraw cementowych z maczka chalcedonitowa i opalem. Badania wykazaly pozytywny wplyw dodatku maczki chalcedonitowej na ograniczenie ekspansji wywolanej reakcja alkalia-krzemionka w stosunku do zapraw bez tego dodatku. Dodatek maczki chalcedonitowej do zapraw cementowych w ilości $20 \%$ obniża ekspansję do bezpiecznego poziomu, nieprzekraczającego po 360 dniach 0,1\% (wedlug normy ASTM C227).

Słowa kluczowe: reakcja alkalia-krzemionka, mączka chalcedonitowa, dodatek mineralny, kruszywo reaktywne, skład cementu

\section{Introduction}

The current development of technology of construction materials does not aim only at improving the properties of the materials but also at the maintenance of the existing structures. The degradation of construction materials can be caused by both the aggressive environmental impact and the

\section{Wprowadzenie}

Rozwój technologii materiałów budowlanych polega nie tylko na ulepszaniu ich właściwości, ale także na dbałości o już istniejące konstrukcje. Niszczenie materiałów budowlanych może być spowodowane zarówno agresywnym działaniem środowiska, jak i korozją wewnętrzną materiału. Jednym z groźniejszych 
internal corrosion of the material. The alkali-silica reaction (ASR) is one of the detrimental effects. Since the reaction proceeds very slowly, and its effects and consequences can only be seen after many years, this phenomenon is commonly known as "the cancer of concrete". The alkali-aggregate interaction results in the deterioration of the strength of concrete, the visible signs of which are leaks, cracks and chips. A sodiumpotassium silicate gel or a sodium-potassium-calcium silicate gel is the product of the reaction. It appears in the aggregate cleavage planes, in its pores and also on the surface of the grains. The swelling of the products of the reaction due to the absorption of moisture is the essence of the alkali-aggregate interaction $[1,2]$. The application of mineral additives, industrial waste of varied composition as well as chemical admixtures [3] permits limiting such adverse effects. Chalcedony dust, a waste product of construction aggregates manufacture, can be used as a mineral additive in cements or concretes. This additive can act as a pozzolan and prevent the expansion caused by the alkali-silica reaction.

\section{Materials and testing methods}

\subsection{Cement}

Portland cement CEM I 42.5R with an alkali content of $0.74 \% \mathrm{Na}_{2} \mathrm{O}_{\text {eq }}$ was used in the tests. The chemical composition of the cement is shown in Table 1. The alkali content in all the samples was kept constant at $0.74 \%$ owing to the addition of $\mathrm{K}_{2} \mathrm{SO}_{4}$. oddziaływań jest reakcja alkalia-krzemionka, zachodzi ona bardzo powoli, a jej skutki i następstwa bywają widoczne dopiero po wielu latach, dlatego też w języku potocznym zjawisko to było określane jako „rak betonu". Oddziaływanie alkalia-kruszywo wpływa na pogorszenie wytrzymałości betonu poprzez pojawienie się wycieków, rys i odprysków. Produktem tej reakcji jest żel krzemianu sodowo-potasowego lub żel krzemianu sodowo-potasowo-wapniowego. Pojawia się on w płaszczyznach łupliwości kruszywa, w jego porach, a także na powierzchni ziaren. Istotą oddziaływania alkaliów z kruszywem jest pęcznienie produktów tej reakcji na skutek pochłaniania wilgoci $[1,2]$. Stosowanie dodatków mineralnych, odpadów przemysłowych o zróżnicowanym składzie oraz domieszek chemicznych [3] pozwala na ograniczenie tego rodzaju niekorzystnych oddziaływań. Mączka chalcedonitowa, powstająca jako odpad przy produkcji kruszywa budowlanego, może być wykorzystana jako dodatek mineralny do cementów czy betonów, może on działać jak pucolana i zapobiegać ekspansji wywołanej reakcją alkalia-krzemionka.

\section{Materiały i metodyka badań \\ 2.1. Cement}

Do badań zastosowano cement portlandzki CEM I $42,5 \mathrm{R}$ o zawartości alkaliów równej $0,74 \% \mathrm{Na}_{2} \mathrm{O}_{\text {eq }}$. Skład chemiczny cementu przedstawiono $\mathrm{w}$ tabeli 1. Zawartość alkaliów we wszystkich próbkach była utrzymywana na stałym poziomie wynoszącym $0,74 \%$ poprzez dodatek $\mathrm{K}_{2} \mathrm{SO}_{4}$.

\section{Table 1. Chemical composition of CEM I}

Tabela 1. Skład chemiczny CEMI

\begin{tabular}{|l|c|c|c|c|c|c|c|c|c|c|}
\hline CEMI & $\mathrm{SiO}_{2}$ & $\mathrm{Al}_{2} \mathrm{O}_{3}$ & $\mathrm{Fe}_{2} \mathrm{O}_{3}$ & $\mathrm{CaO}$ & $\mathrm{MgO}$ & $\mathrm{SO}_{3}$ & $\mathrm{~K}_{2} \mathrm{O}_{c}$ & $\mathrm{Na}_{2} \mathrm{C}_{c}$ & eq Na${ }_{2} \mathrm{O}$ & $\mathrm{Cl}^{-}$ \\
\hline Contents [\%] & 17.52 & 5.23 & 2.81 & 60.00 & 1.44 & 3.20 & 0.84 & 0.19 & 0.734 & 0.069 \\
\hline
\end{tabular}

\subsection{Chalcedony dust}

Chalcedony dust with particle size of $<50 \mu \mathrm{m}$ was used in the tests. The particle size of the mineral additive was determined by laser diffraction. The particle size distribution of chalcedony dust is illustrated in Figure 1.

The gradation test of chalcedony dust showed that particles with a diameter of less than $30 \mu$ m accounted for $90 \%$ of the additive, whereas particles with a diameter of less than $22 \mu \mathrm{m}$ accounted for $50 \%$.

The phase composition of chalcedony dust was determined by XRD method, and its diffraction pattern is presented in Figure 2.

\subsection{Mączka chalcedonitowa}

Do badań zastosowano mączkę chalcedonitową o uziarnieniu $<50 \mu \mathrm{m}$. Uziarnienie dodatku mineralnego określono metodą dyfrakcji laserowej. Skład ziarnowy mączki chalcedonitowej przedstawiono na rysunku 1.

Badanie składu granulometrycznego mączki chalcedonitowej wykazało, że 90\% tego dodatku stanowią ziarna o średnicy mniejszej niż $30 \mu \mathrm{m}$, natomiast $50 \%$ to ziarna o średnicy poniżej $22 \mu \mathrm{m}$.

Skład fazowy mączki chalcedonitowej określono metodą rentgenograficzną XRD, a dyfraktogram zamieszczono na rysunku 2. 


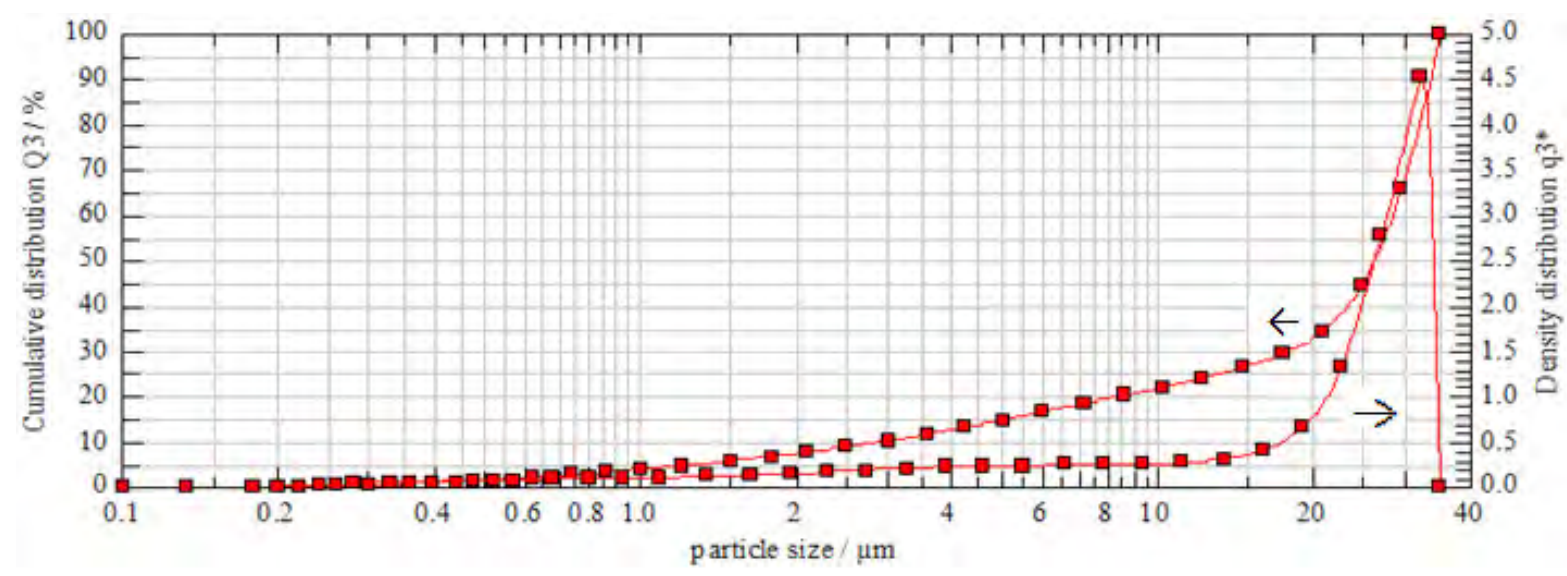

Fig. 1. Particle size distribution of chalcedony dust used in the tests

Rys. 1. Sklad granulometryczny maczki chalcedonitowej wykorzystanej do badań

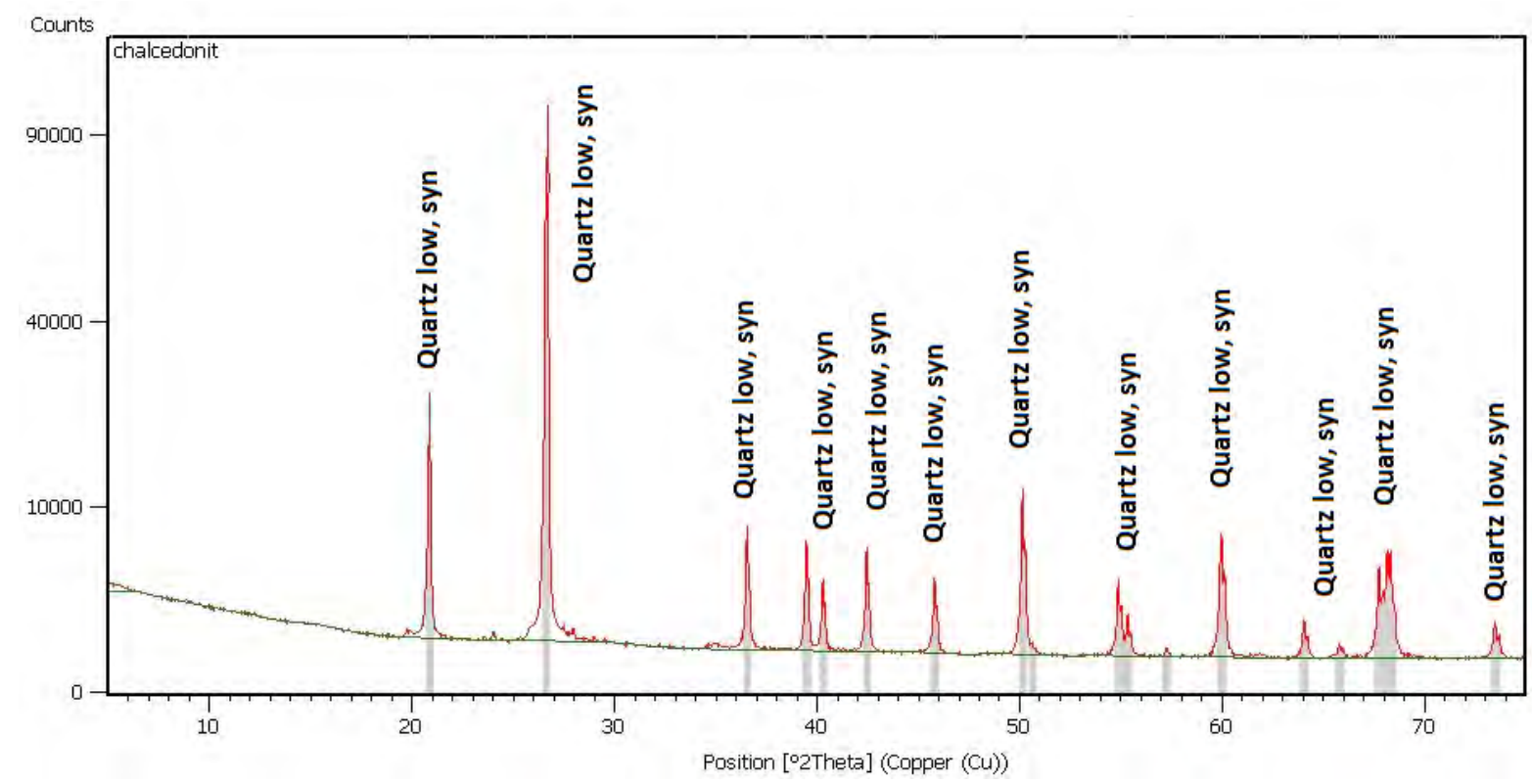

Fig. 2. Diffraction pattern of chalcedony dust Rys. 2. Dyfraktogram maczki chalcedonitowej

Quartz is the main mineral in the phase composition of the dust. The raised background at low angles indicates the presence of amorphous phase. The observations of the microstructure of chalcedonite under the scanning microscope showed regular particles with a compact structure. The EDS analysis performed on the surface of chalcedony dust revealed the silicon mainly as well as oxygen [4].

\subsection{Aggregate}

In order to prepare cement mortars, standard quartz sand was used as an aggregate. However, $6 \%$ of 0.5 1.0 fractions of the sand mass was replaced with opal. Figure 3 shows the diffraction pattern of opal aggregate.
W składzie fazowym mączki występuje głównie kwarc. Podniesienie tła w zakresie niskich kątów świadczy o obecności fazy amorficznej. Obserwacje mikrostruktury chalcedonitu pod mikroskopem skaningowym wykazały występowanie regularnych ziaren o zwartej strukturze. Mikroanaliza rentgenowska EDS na powierzchni mączki chalcedonitowej uwidoczniła obecność głównie krzemu oraz tlenu [4].

\subsection{Kruszywo}

Do wykonania zapraw cementowych jako kruszywo zastosowano normowy piasek kwarcowy, w którym 6\% frakcji 0,5-1,0 zastąpiono opalem. Na rysunku 3 przedstawiono dyfraktogram kruszywa opalowego. 


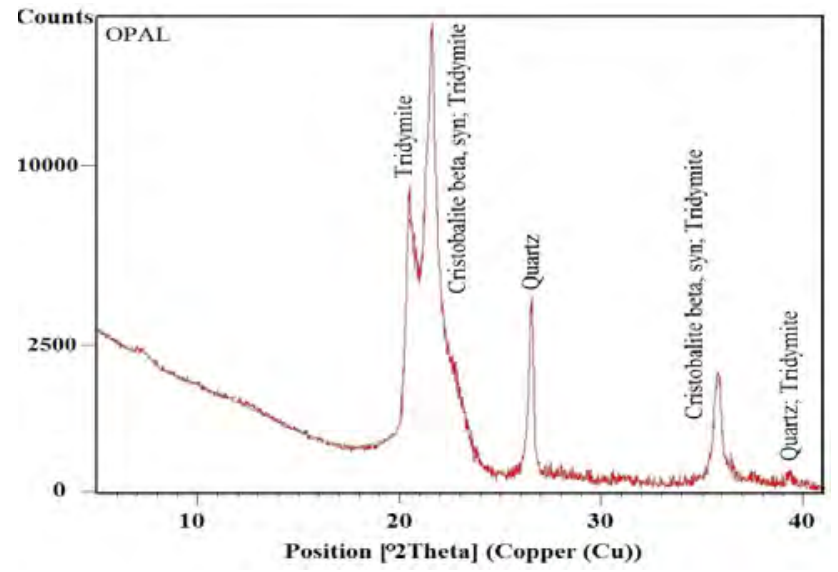

Tridymite, cristobalite and quartz are found in the phase composition of the opal aggregate. The raised background at low angles and wide peaks indicate the presence of amorphous silica. The petrographic analysis of the opal grains revealed that cristobalitetridymite opal (CT opal) was the main component. Fibrous-structured crystalline chalcedony and fine crystalline quartz are the remaining constituents of the rock. There are also small amounts of nonsiliceous minerals such as goethite and talc $[5,6]$. The examination of the potential reactivity of opal aggregate by chemical method as set out in the ASTM C289 [7] showed that opal was a reactive aggregate and thus could be used as an expansive component of aggregates [8].

\subsection{Testing methods}

A long-term method as set out in the ASTM C227 $[9,10]$ was used to evaluate the effect of chalcedony dust on the reaction of alkalis with the reactive aggregate in cement mortars. The method consists in measuring linear changes in the cement mortar bars of $25 \times 25 \times 250 \mathrm{~mm}$. Five series of specimens, in which different amounts of cement (10-25\%) were replaced with chalcedony dust, were prepared for the tests. The symbols and contents of the cement mortar specimens are given in Table 2.
Fig. 3. Diffraction pattern of opal aggregate

Rys. 3. Dyfraktogram kruszywa opalowego

W składzie fazowym kruszywa opalowego występuje trydymit, cristobalit oraz kwarc. Podniesienie tła w zakresie niskich kątów oraz duże szerokości pików świadczą o występowaniu krzemionki amorficznej. Analiza petrograficzna ziaren opalu wykazała, że głównym składnikiem jest opal cristobalitowo-trydymitowy (opal CT). Pozostałymi składnikami skały są: krystaliczny chalcedon właściwy o włóknistej strukturze oraz drobnokrystaliczny kwarc. W skale występują również niewielkie ilości minerałów niekrzemionkowych, takich jak goethyt oraz talk [5, 6]. Badania potencjalnej reaktywności kruszywa opalowego metodą chemiczną według normy ASTM C289 [7] wykazały, że opal jest kruszywem reaktywnym i może być zastosowany jako składnik ekspansywny kruszywa [8].

\subsection{Metody badawcze}

Do oceny wpływu mączki chalcedonitowej na przebieg reakcji alkaliów z kruszywem reaktywnym w zaprawach cementowych zastosowano metodę długoterminową według normy ASTM C227 $[9,10]$. Metoda polega na pomiarze zmian liniowych beleczek zaprawy cementowej o wymiarach $25 \times 25 \times 250 \mathrm{~mm}$. Do badań przygotowano 5 serii próbek, w których różne ilości cementu (10-25\%) zastąpiono dodatkiem mączki chalcedonitowej. Oznaczenie i skład próbek zapraw cementowych zamieszczono w tabeli 2 .

Table 2. Symbols and content of specimens prepared for the tests as set out in the ASTM C227

Tabela 2. Oznaczenie i skład próbek przygotowanych do badań wedtug normy ASTM C227

\begin{tabular}{|c|c|c|c|c|}
\hline Specimen symbol & w/cratio & $\begin{array}{c}\text { Cement content } \\
{[\%]}\end{array}$ & $\begin{array}{c}\text { Chalcedony dust content } \\
{[\%]}\end{array}$ & $\begin{array}{c}\mathrm{Na}_{2} \mathrm{O}_{\text {eq }} \text { content } \\
{[\%]}\end{array}$ \\
\hline OP & 0.45 & 100 & 0 & 0.74 \\
\hline$O P+10 \% M C$ & 0.45 & 90 & 10 & 0.74 \\
\hline$O P+15 \% M C$ & 0.45 & 85 & 15 & 0.74 \\
\hline$O P+20 \% M C$ & 0.45 & 80 & 20 & 0.74 \\
\hline$O P+25 \% M C$ & 0.45 & 75 & 25 & 0.74 \\
\hline
\end{tabular}


The cement mortar specimens were stored at $38^{\circ} \mathrm{C}$ $\left( \pm 2^{\circ} \mathrm{C}\right) 24$ hours after moulding. The measurements of the bar length were taken on the specimens cooled to $23^{\circ} \mathrm{C}$ after 14 days and then after $1,2,3,4,6,9$, 12 months.

\section{Test results}

\subsection{Expansion of cement mortars}

The results of the measurements of expansion of the cement mortars with opal and the cement mortars with opal and chalcedony dust tested as set out in the ASTM C227 are illustrated in Figure 4. The graph presents the dependence of expansion versus the exposure time for the cement mortars curing at $38^{\circ} \mathrm{C}$ $\left( \pm 2^{\circ} \mathrm{C}\right)$. In Figure 4, the red line represents the limit values of the expansion, indicating the presence of corrosion.
Próbki zapraw cementowych po 24 godzinach od zaformowania przechowywano w temperaturze $38^{\circ} \mathrm{C}$ $\left( \pm 2^{\circ} \mathrm{C}\right)$. Pomiaru długości beleczek dokonywano na ostudzonych do temperatury $23^{\circ} \mathrm{C}$ próbkach po 14 dniach i następnie po $1,2,3,4,6,9,12$ miesiącach.

\section{Wyniki badań}

\subsection{Ekspansja zapraw cementowych}

Wyniki pomiarów ekspansji badanych zapraw cementowych z opalem oraz zapraw cementowych z opalem i mączką chalcedonitową według normy ASTM C227 przedstawiono graficznie na rysunku 4. Wykres prezentuje zależność ekspansji w funkcji czasu ekspozycji dla zapraw cementowych dojrzewających w temperaturze $38^{\circ} \mathrm{C}\left( \pm 2^{\circ} \mathrm{C}\right)$. Czerwoną linią ciągłą zaznaczono graniczne wartości ekspansji, wskazujące na występowanie procesów korozyjnych.

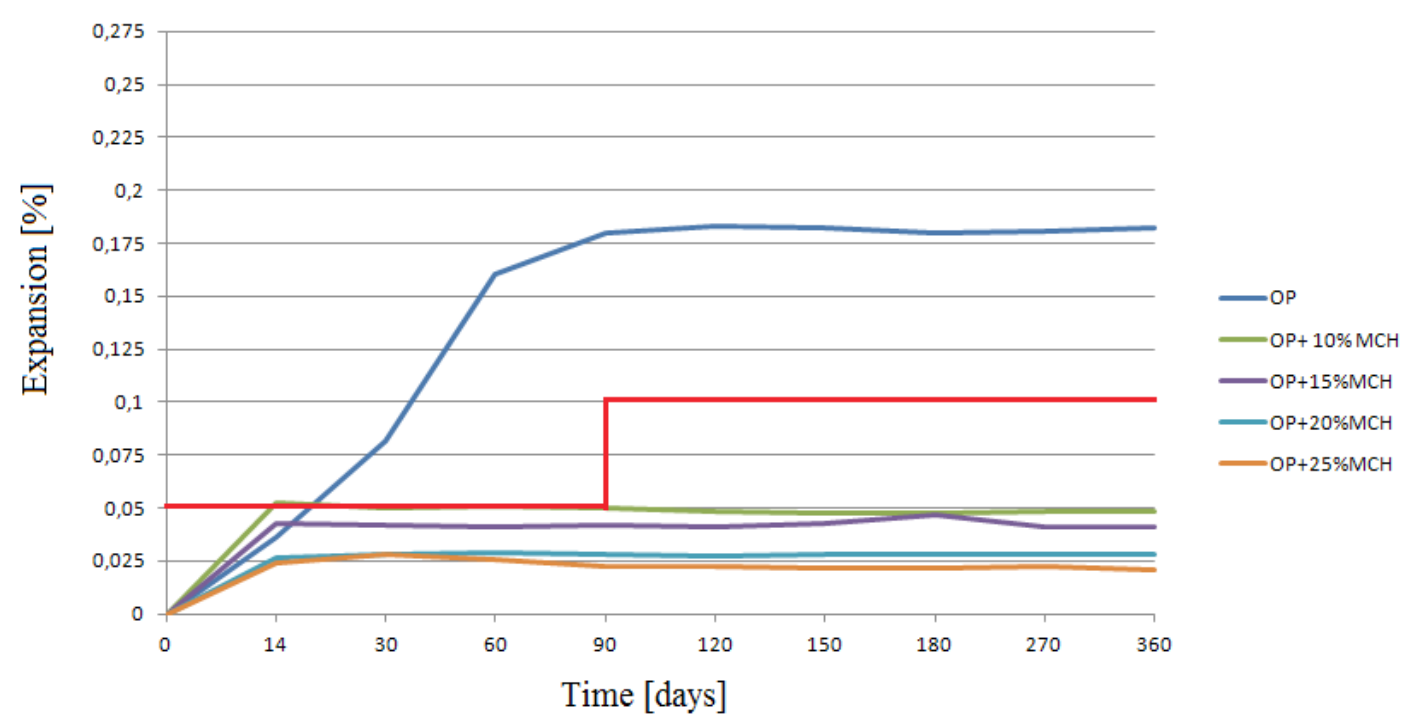

Fig. 4. Results of expansion of cement mortars as set out in the ASTM C227

Rys. 4. Wyniki ekspansji zapraw cementowych wedtug normy ASTM C227

The results of the tests show that chalcedony dust used as a mineral additive in cement influences the reduction of the expansion caused by the alkaline reaction. The specimens of the cement mortars with opal and without the mineral additive reached a high expansion rate of over $0.05 \%$ after 3 months and $0.1 \%$ after 6 months. The rate of expansion in the specimens with the addition of chalcedony dust was significantly lower. A favourable rate of expansion was observed in the specimens with a chalcedony dust content of $25 \%$ and $20 \%$. In these specimens, the rate of expansion kept increasing to $0.025 \%$ till the $14^{\text {th }}$ day, and then levelled off to remain stable. The specimens with a mineral additive content of $10 \%$ and $15 \%$ did not reach high expansions rates
Zaprezentowane wyniki badań świadczą o tym, że mączka chalcedonitowa zastosowana jako dodatek mineralny do cementu wpływa na zmniejszenie ekspansji wywołanej reakcją alkaliczną. Próbki zapraw cementowych $\mathrm{z}$ opalem i bez dodatku mineralnego osiągnęly wysoki poziom ekspansji przekraczający wartość $0,05 \%$ po 3 miesiącach oraz $0,1 \%$ po 6 miesiącach. Poziom ekspansji w próbkach $\mathrm{z}$ dodatkiem mączki chalcedonitowej był znacznie niższy. Korzystny poziom ekspansji zaobserwowano w próbkach z $25 \%$ oraz $20 \%$ dodatkiem mączki chalcedonitowej. W tych próbkach wartość ekspansji wzrastała do 14 dnia do poziomu $0,025 \%$, a następnie została utrzymana na stałym poziomie. Próbki z dodatkiem mineralnym w ilości 10\% i 15\% również nie osiągnęły wy- 
either, despite the fact that in the specimen with an additive content of $10 \%$ the expansion rate exceeded $0.05 \%$ after 3 months. The annex to the ASTM C227 specifies that exceeding this expansion rate causes corrosive processes; however, the aggregate can be deemed harmless if the expansion of the specimens does not exceed $0.01 \%$ within 6 months.

\subsection{Analysis of the microstructure of the cement mortars}

After 12 months, the microstructure of the cement mortars curing at $38^{\circ} \mathrm{C}\left( \pm 2^{\circ} \mathrm{C}\right)$ was examined. The figures 5 and 6 show the SEM images along with the EDS analysis of the OP specimens as well as the OP $+20 \% \mathrm{MCH}$ specimens.

a)

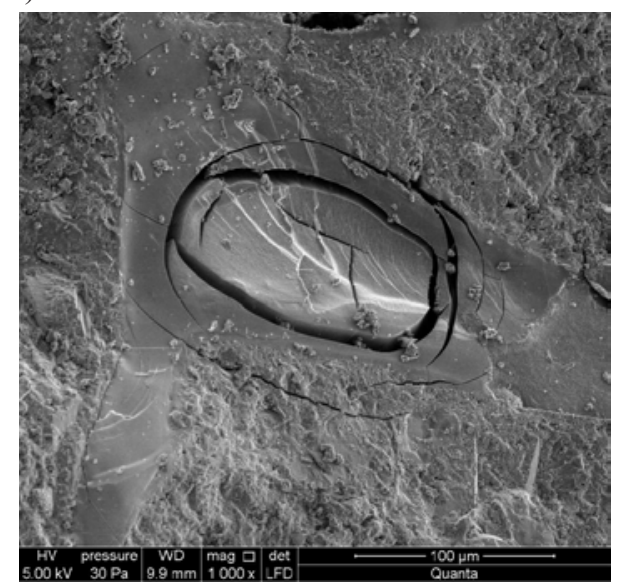

sokich wartości ekspansji, mimo że w próbce z 10\% dodatkiem wartość ekspansji przekroczyła $0,05 \%$ po 3 miesiącach. Załącznik do normy ASTM C227 wskazuje, że przekroczenie tej wielkości ekspansji powoduje procesy korozyjne, lecz jeśli w przeciągu 6 miesięcy ekspansja próbek nie przekroczy poziomu $0,01 \%$, to kruszywo można uznać za nieszkodliwe.

\subsection{Analiza mikrostruktury zapraw cementowych}

Po upływie 12 miesięcy wykonano badanie mikrostruktury zapraw cementowych dojrzewających w temperaturze $38^{\circ} \mathrm{C}\left( \pm 2^{\circ} \mathrm{C}\right)$. Na rysunkach 5-6 przedstawiono zdjęcia SEM wraz z analizą EDS próbek OP oraz $\mathrm{OP}+20 \% \mathrm{MCH}$. b)

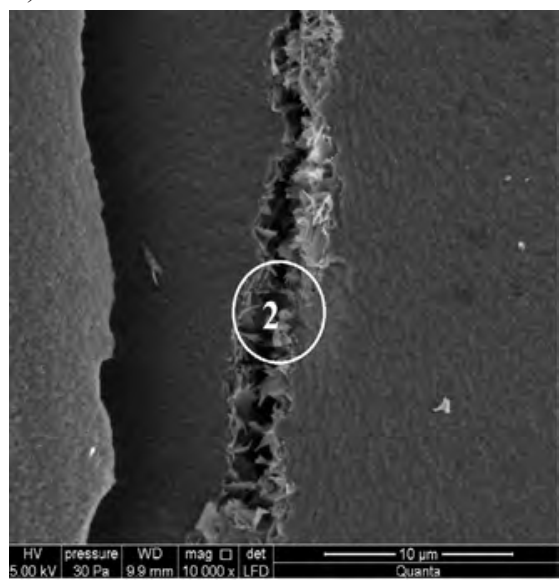

c)

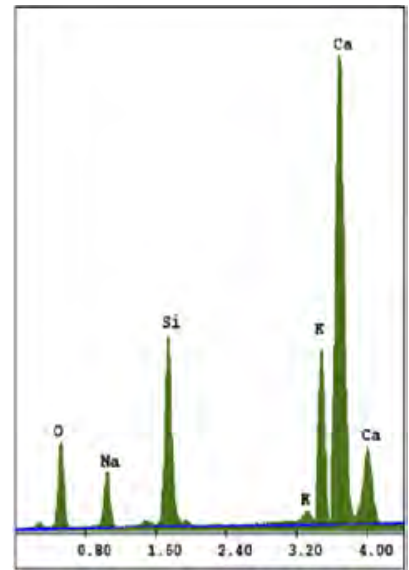

Fig. 5 a) Cracked aggregate grain in the mortar with opal (OP), b) sodium-potassium-calcium silicate gel in the cracked aggregate in the specimen with opal $(O P), c)$ microanalysis in region 2

Rys. 5 a) Speckane ziarno kruszywa $w$ zaprawie z opalem (OP), b) żel krzemianu sodowo-potasowo-wapniowego w spękanym kruszywie w próbce z opalem (OP), c) mikroanaliza w obszarze 2

a)

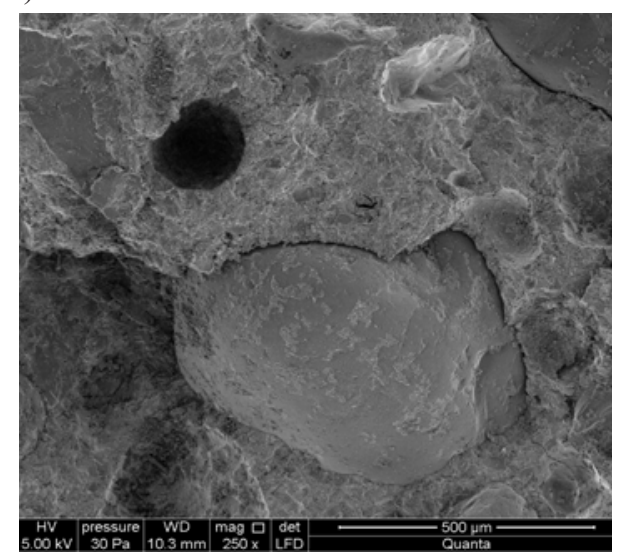

b)

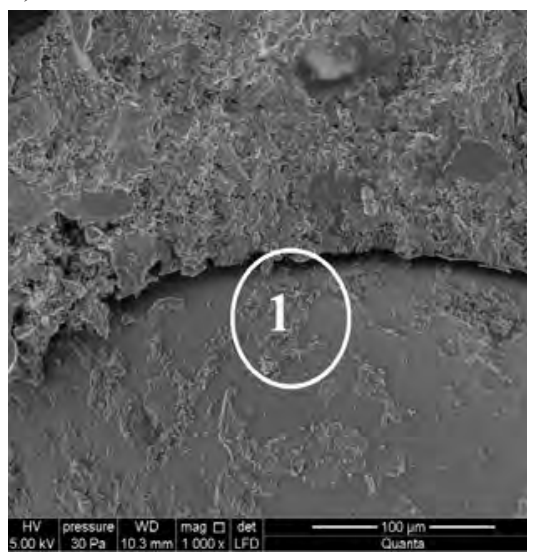

c)

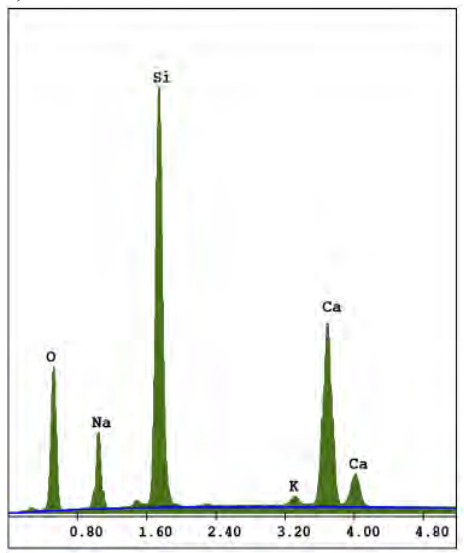

Fig. 6 a) Aggregate grain in the cement mortar with chalcedony dust content of $20 \%(O P+20 \%$ MC), b) Products of the alkali-silica reaction on the surface of an aggregate grain in the specimen with chalcedony dust content of $20 \%(O P+$ $20 \% M C)$, c) EDS analysis in the microregion 1

Rys. 6 a) Ziarno kruszywa w zaprawie cementowej z 20\% dodatkiem maczki chalcedonitowej (OP + 20\% MC), b) produkty reakcji alkalia-krzemionka na powierzchni ziarna kruszywa w próbce z 20\% dodatkiem maczki chalcedonitowej (OP + 20\% MC), c) analiza EDS w mikroobszarze 1 
Multiple aggregate grain cracks, characteristic of the alkaline reaction, were observed in the specimens of cement mortar with opal without the mineral additive $(\mathrm{OP})$, with a high expansion rate. The EDS analysis in the region of the opal grain confirmed the presence of a sodium-potassium-calcium silicate gel (Fig. 5). This is evidenced by the considerable amounts of calcium, potassium and sodium present both on the surface of the grains and in the micro-cracked regions. In contrast, only a few cracks of the microstructure were observed in the specimens with chalcedony dust content of $20 \%$, and the reaction products on the surface of the particles in these specimens had a reduced sodium and potassium content as against the specimens without chalcedony dust.

\section{Discussion}

The addition of chalcedony dust to cement mortars permits limiting the expansion caused by the alkalisilica reaction. The magnitude of the expansion of the mortars with reactive opal aggregate and the chalcedony dust additive depends on the amount of the additive used. The application of $20-25 \%$ of chalcedony dust in the cement permits keeping the expansion at a stable and safe level without inducing corrosion. This amount of the mineral additive in cement mortars does not impair the strength properties of cement composites [11]. The positive effect of the chalcedony dust additive on the expansion of cement mortars caused by the alkalisilica reaction occurs due to the pozzolanic properties of this additive. The silica in the pozzolanic reaction reacts with the calcium hydroxide that is released by the hydration of cement and increases the amount of C-S-H hydrated calcium silicate with a reduced $\mathrm{C}: \mathrm{S}$ ratio [12]. The newly created $\mathrm{C}-\mathrm{H}-\mathrm{S}$ phase is characterised by a lower C:S ratio than the $\mathrm{C}-\mathrm{H}-\mathrm{S}$ phase created as a result of the hydration of cement as well as by the ability to incorporate sodium and potassium ions from the pore solution. The addition of chalcedony dust can contribute to a uniform distribution of $\mathrm{Na}^{+}$and $\mathrm{K}^{+}$ions in concrete so that they do not concentrate around the aggregate grains $[13,14]$. The examination of the microstructure as well as the EDS analysis of the cement mortars with and without the chalcedony dust additive confirm the thesis that the reduction of alkaline expansion can be caused by the pozzolanic reaction. The EDS analysis of the specimen with opal (OP) showed the sodium-potassium-calcium gel on the surface of the opal grains as a product of the alkali-silica
W próbkach zapraw cementowych z opalem bez dodatku mineralnego (OP), których poziom ekspansji był wysoki, zaobserwowano liczne charakterystyczne dla reakcji alkalicznej spękania ziarna kruszywa. Analiza EDS w obszarze ziarna opalu potwierdziła występowanie żelu krzemianu sodowo-wapniowo-potasowego (rys. 5). Świadczą o tym znaczne ilości wapnia, potasu oraz sodu występujące na powierzchni ziarna oraz w obszarach mikrospękań. Natomiast w próbkach z dodatkiem mączki chalcedonitowej w ilości $20 \%$ zaobserwowano tylko nieliczne spękania mikrostruktury. Natomiast produkty reakcji powstałe na powierzchni ziarna $\mathrm{w}$ tych próbkach charakteryzowały się zmniejszoną zawartością sodu i potasu w porównaniu z próbkami bez dodatku mączki chalcedonitowej.

\section{Dyskusja}

Dodatek mączki chalcedonitowej do zapraw cementowych pozwala na ograniczenie ekspansji wywołanej reakcją alkalia-krzemionka. Wielkość ekspansji zapraw z reaktywnym kruszywem opalowym i dodatkiem mączki chalcedonitowej zależy od ilości wprowadzonego dodatku. Zastosowanie mączki chalcedonitowej w ilości 20-25\% masy cementu pozwala na utrzymanie ekspansji na stałym bezpiecznym poziomie niepowodującym procesów korozyjnych. Taka ilość dodatku mineralnego w zaprawach cementowych nie powoduje pogorszenia właściwości wytrzymałościowych kompozytów cementowych [11]. Korzystny wpływ dodatku mączki chalcedonitowej na ekspansję zapraw cementowych, wywołaną reakcją alkalia-krzemionka, spowodowany jest właściwościami pucolanowymi tego dodatku. Krzemionka w reakcji pucolanowej wchodzi $\mathrm{w}$ reakcję $\mathrm{z}$ wodorotlenkiem wapniowym, który jest uwalniany $\mathrm{w}$ procesie hydratacji cementu, i zwiększa ilość uwodnionych krzemianów wapniowych typu C-S-H o obniżonym stosunku $\mathrm{C}: \mathrm{S}$ [12]. Nowo utworzona faza C-S-H charakteryzuje się niższym stosunkiem $\mathrm{C}$ :S niż faza C-S-H, powstająca w wyniku hydratacji cementu, oraz zdolnością włączania jonów sodu i potasu z roztworu porowego. Zastosowany dodatek mączki chalcedonitowej może przyczynić się do równomiernego rozprowadzenia jonów $\mathrm{Na}^{+} \mathrm{i} \mathrm{K}^{+} \mathrm{w}$ betonie, stąd nie koncentrują się wokół ziaren kruszywa [13, 14]. Badania mikrostruktury oraz analiza EDS zapraw cementowych bez dodatku oraz z dodatkiem mączki chalcedonitowej potwierdzają tezę, iż ograniczenie ekspansji alkalicznej może być spowodowane przez reakcję pucolanową. Analiza EDS próbki z opalem (OP) wykazała obecność na powierzchni ziarna opalu żelu sodowo-potasowo- 
reaction, whereas in the $\mathrm{OP}+20 \% \mathrm{MCH}$ specimens, a significant reduction in the amount of alkalis, most likely incorporated into the C-S-H phase, newly formed in the pozzolanic reaction, was observed.

\section{Conclusions}

The following conclusions can be drawn based on the analysis of the test results:

1. The tests conducted as set out in the ASTM C227 showed that the addition of $20 \%$ of chalcedony dust permits both limiting the expansion caused by the alkali-silica reaction and keeping it at a stable and safe level without inducing corrosion.

2. The expansion rate in the cement mortars with chalcedony dust contents of $10 \%$ and $15 \%$ exceeded $0.05 \%$ after 3 months. However, in accordance with the standard, this rate of expansion does not result in any corrosive processes in the cementbased composites.

3. The results of the examination of the microstructure are consistent with the results of the tests conducted as set out in the ASTM C227. A cracked sodiumcalcium-potassium silicate gel with a high alkali content was observed in the mortars with opal and without chalcedony dust (OP) exhibiting significant expansion. In contrast, no microstructural cracks characteristic of the alkali-silica reaction were observed in the specimens with the mineral additive content of $20 \%$. -wapniowego jako produktu reakcji alkalia-krzemionka. Natomiast w próbkach OP $+20 \% \mathrm{MCH}$ zaobserwowano znaczne zmniejszenie ilości alkaliów, które najprawdopodobniej zostały wbudowane w nowo powstałą w reakcji pucolanowej fazę C-S-H.

\section{Wnioski}

Wykonane badania pozwoliły na sformułowanie następujących wniosków:

1. Badania wykonane według normy ASTM C227 wykazały, że dodatek mączki chalcedonitowej w ilości $20 \%$ w stosunku do masy cementu pozwala na ograniczenie ekspansji wywołanej reakcją alkalia-krzemionka i utrzymanie jej na stałym bezpiecznym poziomie niepowodującym procesów korozyjnych.

2. Wartość ekspansji w zaprawach cementowych z dodatkiem mączki chalcedonitowej w ilości 10\% i $15 \%$ przekroczyła $0,05 \%$ po 3 miesiącach, jednak zgodnie z normą taki poziom wartości ekspansji nie prowadzi do procesów korozyjnych w kompozytach cementowych.

3. Badania mikrostruktury pokrywają się $\mathrm{z}$ badaniami ekspansji wedhug normy ASTM C227. W zaprawach z opalem i bez dodatku mączki chalcedonitowej (OP), wykazujących znaczną ekspansję, zaobserwowano występowanie spękanego żelu krzemianu sodowo-wapniowo-potasowego o wysokiej zawartości alkaliów. Natomiast w próbkach z 20\% dodatkiem mineralnym nie zaobserwowano charakterystycznych dla reakcji alkalia-krzemionka spękań mikrostruktury.

\section{References}

[1] Owsiak Z., Reakcje kruszyw krzemionkowych z alkaliami w betonie, Polski Biuletyn Ceramiczny No. 72, Wydawnictwo Naukowe Akapit, Kraków 2002.

[2] Kurdowski W., Chemia cementu i betonu, SPC, Kraków 2010.

[3] Owsiak Z., Zapała-Sławeta J., The course of the alkali-aggregate reaction in the presence of lithium nitrate, Ceramics-Silikaty, Vol. 57, no. 2, 2013, pp. 138-145.

[4] Owsiak Z., Mazur A., Effect of chalcedony dust on ASR in mortars of reactive ag-gregate, Procedia Engineering 108, 2015, pp. 475-480.

[5] Manecki A., Muszyński M. (red.), Przewodnik po petrografii, Uczelniane Wydawnictwo Naukowo-Dydaktyczne, Kraków 2008.

[6] Graetsh H., Gies H., Topalovi I., NMR, XRD and IR study on microcrystalline opals, Physics and Chemistry of MInerals, 1994, 21, pp. 166-175.

[7] ASTM C289-94 Potential Alkali-Silica Reactivity of Aggregates (Chemical Method), Annual Book of ASTM Standards.

[8] Owsiak Z., Zapała-Sławeta J., The alkaline reactivity of opal in mortars modified with lithium nitrate, Procedia Engineering 65, 2013, pp. 57-62.

[9] ASTM C227-10 Standard Test Method for Potential Alkali Reactivity of Cement-Aggregate Combinations (MortarBar Method), Annual Book of ASTM Standards.

[10] Zapała-Sławeta J., Owsiak Z., The role of lithium compounds in mitigating alkali-gravel aggregate reaction, Construction and Building Materials 115, 2016, pp. 299-303. 
[11] Owsiak Z., Mazur A., Analysing the pozzolanic reactivity of chalcedony dust in cement paste, Konferencja WMCAUS, Praga12.06-16.06.2017, konferencja indeksowana w Web of Science.

[12] Glasser F.P., Marr J., The effect of mineral additives on the composition of cement pore fluids, Proceedings of the British Ceramic Society, 1984, 35, pp. 419-428.

[13] Owsiak Z., Microstructure of alkali-silica reaction products in conventional standard and accelerated testing, Ceramics-Silikáty, 47 (3) 2003, pp. 108-115.

[14] Foroughi M., Tabatabaei R., Shamsadeini M., Effect of Natural Pozzolans on the Alkali-Silica Reaction of Aggregates in Real Concrete Specimens, Journal on Basic and Applied Scientific Research, May 2012, pp. 5248-5254.

\section{Acknowledgments:}

This work was supported by Kielce University of Technology, Grant No. 02.05.00/2.01.01.01.0012 MNSP.BKTO.14.003

\section{Podziękowania:}

Praca była finansowana przez Politechnikę Świętokrzyska, grant nr 02.05.00/2.01.01.01.0012 MNSP.BKTO.14.003 